RAFAEL TAVARES BASSOLI

\title{
Personalidade jurídica de entes de Direito Canônico no ordenamento civil brasileiro: \\ passado e presente
}

Dissertação de Mestrado

Orientador: Professor Titular Dr. Ignacio Maria Poveda Velasco

UNIVERSIDADE DE SÃO PAULO

FACULDADE DE DIREITO

São Paulo

2020 


\title{
Personalidade jurídica de entes de Direito Canônico no ordenamento civil brasileiro: \\ passado e presente
}

Dissertação de mestrado apresentada à Banca Examinadora do Programa de Pós-Graduação em Direito, da Faculdade de Direito da Universidade de São Paulo, como exigência parcial para obtenção do título de Mestre em Direito, na área de Direito Civil, subárea História do Direito, na linha de pesquisa Direito e História, projeto acadêmico Direto das Fontes, sob a orientação do Professor Titular Dr. Ignacio Maria Poveda Velasco.

\section{UNIVERSIDADE DE SÃO PAULO \\ FACULDADE DE DIREITO}

\author{
São Paulo
}




\title{
Catalogação da Publicação \\ Serviço de Biblioteca e Documentação Faculdade de Direito da Universidade de São Paulo
}

\author{
Bassoli, Rafael Tavares \\ Personalidade jurídica de entes de Direito Canônico \\ no ordenamento civil brasileiro: passado e presente \\ ; Rafael Tavares Bassoli ; orientador Ignacio Maria \\ Poveda Velasco -- São Paulo, 2020. \\ 145 \\ Dissertação (Mestrado - Programa de Pós-Graduação em \\ Direito Civil) - Faculdade de Direito, Universidade \\ de São Paulo, 2020. \\ 1. história do direito brasileiro. 2. direito \\ canônico. 3. pessoas jurídicas. 4. personalidade \\ jurídica. 5. Acordo Brasil - Santa Sé. I. Poveda \\ Velasco, Ignacio Maria, orient. II. Título.
}


Banca Examinadora

Prof. Dr.:

Instituição:

Julgamento:

Prof. Dr.:

Instituição:

Julgamento:

Prof. Dr.:

Instituição:

Julgamento: 


\section{AGRADECIMENTOS}

Agradeço a Deus e a Nossa Senhora pela Graça de ter iniciado e chegado ao final deste trabalho.

Agradeço ao Professor Ignacio M. Poveda Velasco por ter aceitado este desafio e pela inestimável contribuição e lições de vida durante as reuniões e conversas proporcionadas por este trabalho.

Agradeço aos meus pais, pelo esforço e exemplo de vida que me fizeram chegar até aqui.

Agradeço, finalmente, à minha esposa Mariana. Sem o seu estímulo, paciência e, principalmente amor, nunca teria enfrentado e superado este desafio. 


\section{DEDICATÓRIA}

Aos meus filhos, Pedro, Maria Teresa e Francisco. 


\section{RESUMO}

Este trabalho analisa a situação do direito luso-brasileiro, desde o descobrimento do Brasil até os dias atuais, para investigar o tratamento dado às pessoas jurídicas de direito canônico dentro desse ordenamento. Busca-se entender se o reconhecimento de tais entes sempre aconteceu e sob quais condições. Em especial, foi dado maior destaque (i) à natureza jurídica dos entes de Direito Canônico; (ii) à forma de constituição e reconhecimento da pessoa jurídica; (iii) ao modo de representação dessas pessoas jurídicas dentro do ordenamento; e (iv) ao nível de liberdade que os entes de Direito Canônico possuíam para exercer atos da vida civil. O motivo que nos levou a empreender este estudo foi verificar, na vida prática, as dificuldades que as pessoas jurídicas de Direito Canônico enfrentam para serem reconhecidas pelo nosso ordenamento jurídico, e os prejuízos que tais dificuldades acarretam para o desenvolvimento de suas missões. O objetivo do trabalho é apresentar um panorama tão exaustivo quanto possível da história das pessoas jurídicas de Direito Canônico dentro do ordenamento luso-brasileiro, de forma a fornecer ao legislador, aos estudiosos do tema e operadores do direito bases para, entendendo o rico passado das relações Estado-Igreja no Brasil (e, antes, em Portugal), e, assim, poderem propor soluções para os problemas atuais, aproveitando o que funcionou e rejeitando o que fracassou. Finalmente, para estimular a discussão, também propomos aqui neste trabalho algumas possíveis soluções para os problemas práticos encontrados.

Palavras-chave: história do direito brasileiro; direito canônico; pessoas jurídicas; personalidade jurídica; . 


\begin{abstract}
This work analyses the situation of the Portuguese-Brazilian law, from the discovery of Brazil up to the current days, in order to investigate the treatment given to the legal entities of Canon Law within such legal system. It is aimed to understand if the acceptance of such entities has always been verified and under what conditions. In particular, more evidence was given (i) to the legal nature of the entities of Canon Law; (ii) to the means of incorporation and recognition of the legal entities; (iii) to the forms of representation of such legal entities in the legal system; and (iv) to the level of freedom that the Canon Law entities had to perform acts of the civil life. What motivates us us to carry out this study is to have verified, in practical life, the difficulties faced by the Canon Law entities in order to be accepted as legal entities by our legal system and the consequent damages that such difficulties bring to the development of their purposes. The scope of this work is to present a review, as exhaustive as possible, of the history of the Canon Law legal entities inside the Portuguese-Brazilian legal system, so that the legislator, the scholars interested in this subject and legal professionals will have the basis to, once understood the rich history of the State-Church relations in Brazil (and, prior to that, in Portugal) be able to propose solutions to the current problems, making use of what worked and discarding what failed. Finally, in order to stimulate the discussion, we too propose a few possible solutions in this work to the practical problems identified.
\end{abstract}

Keywords: history of Brazilian law; canon law; legal entities; legal status; Brazil - Holy See Treaty. 


\section{SUMÁRIO}

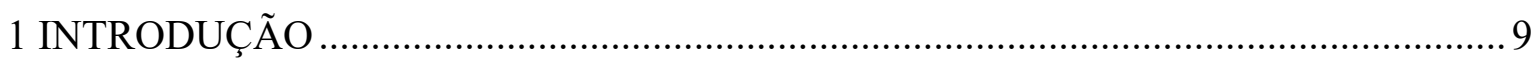

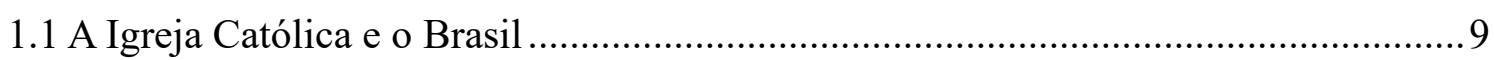

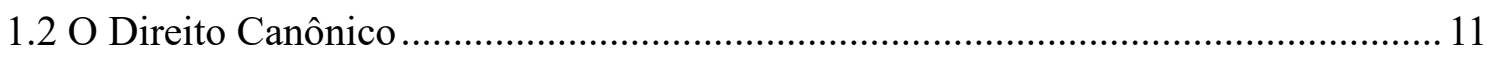

1.3 Colocação do problema e hipóteses de solução ............................................................ 12

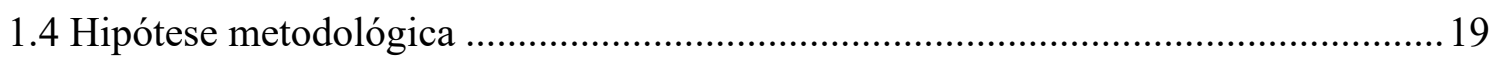

2 O PASSADO: ANÁLISE DO DIREITO LUSO-BRASILEIRO......................................... 21

2.1 Do Descobrimento até as Ordenações Filipinas ………………………………….......

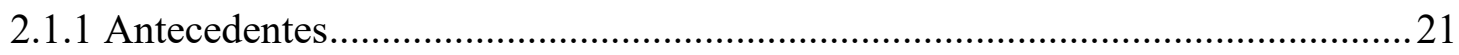

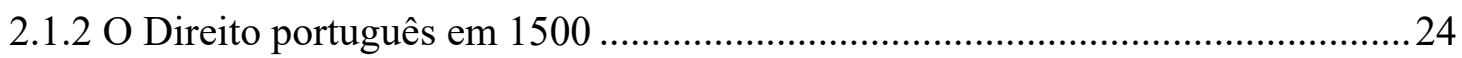

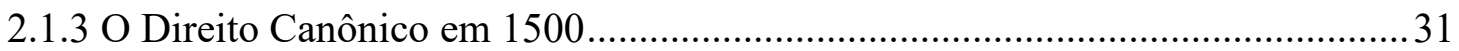

2.1.3.1 Breves acenos ao tratamento das pessoas jurídicas de Direito Canônico pelo

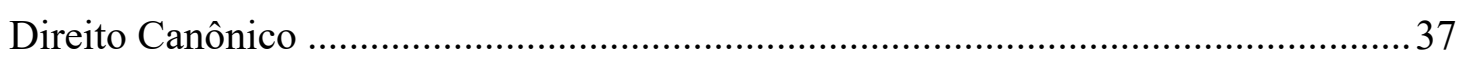

2.1.4 O tratamento das pessoas jurídicas de Direito Canônico nas Ordenações até 1603

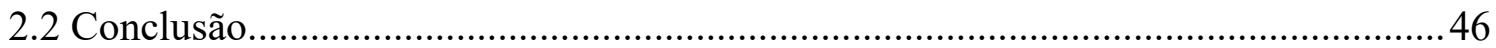

2.3 Das Ordenações Filipinas até a Independência.........................................................46

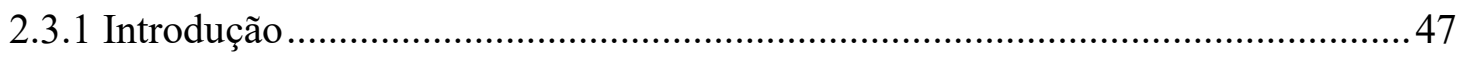

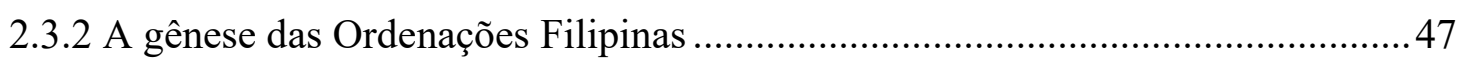

2.3.3 O direito subsidiário nas Ordenações Filipinas ...................................................50

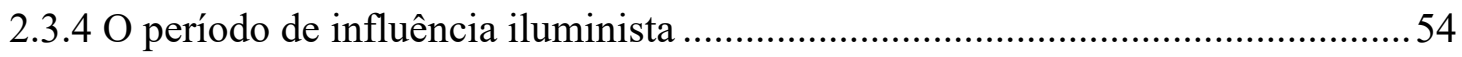

2.3.5 O período de influência liberal e a Independência do Brasil................................56

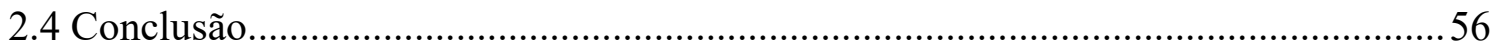

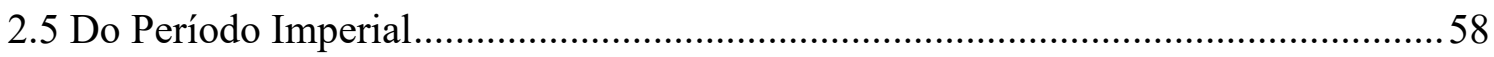

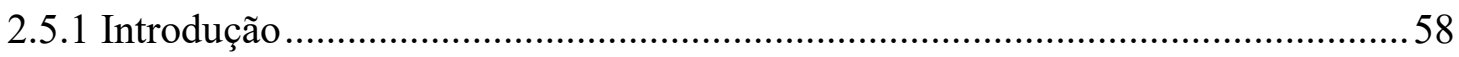

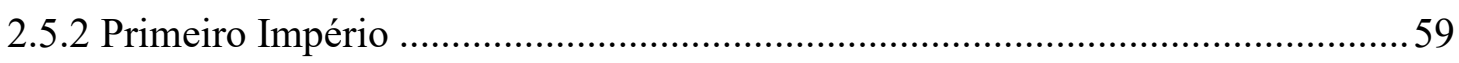

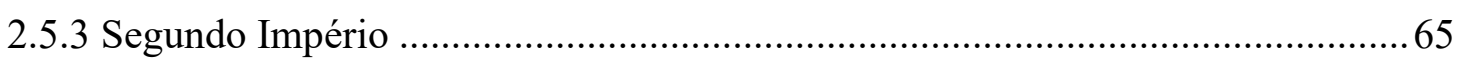

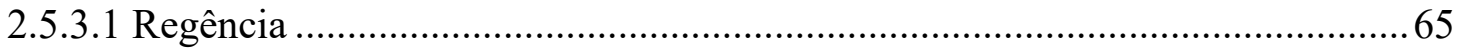

2.5.3.2 Maioridade e reinado de dom Pedro II .............................................................. 66

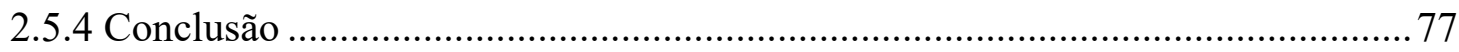

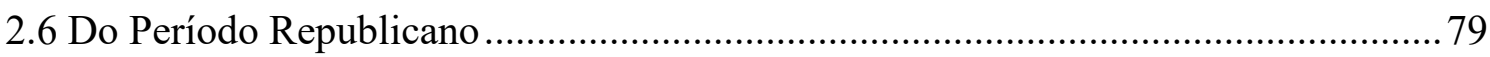

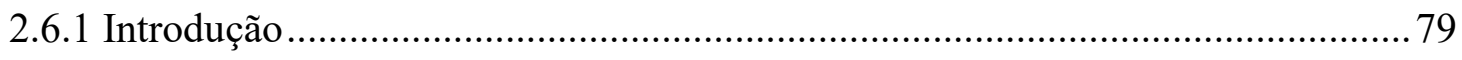


2.6.2 República Velha

2.6.3 O Código Civil de 1916

2.6.4 O Código de Direito Canônico de 1917 e breves notas sobre o tratamento dado às pessoas jurídicas .90

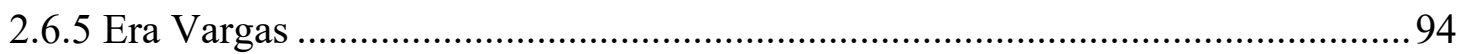

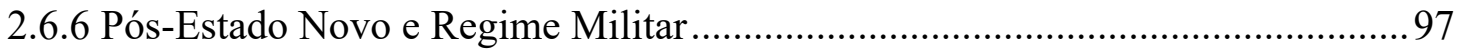

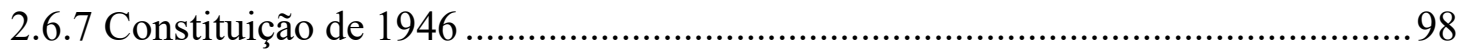

2.6.8 Regime Militar e Constituição de 1967 ...............................................................98

2.6.9 Constituição de 1969, Lei de Registros Públicos e um olhar para a

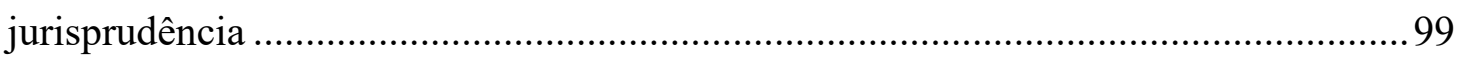

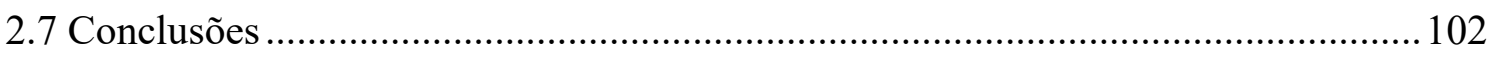

3 O PRESENTE: A REDEMOCRATIZAÇÃO, A CONSTITUIÇÃO DE 1988, O CÓDIGO CIVIL DE 2002 E O ACORDO BRASIL-SANTA-SÉ .................................................. 104

3.1 Breves acenos ao Código de Direito Canônico de 1983 e o novo tratamento das pessoas

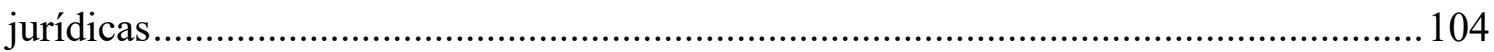

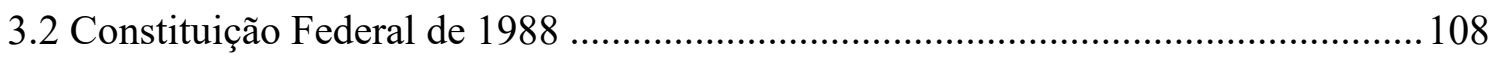

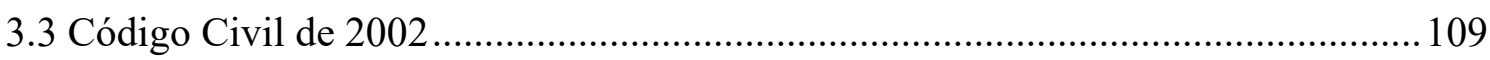

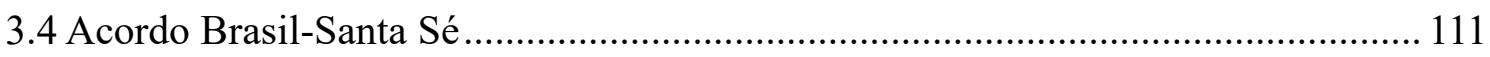

4 O FUTURO: PROBLEMATIZAÇÃO E PROPOSTAS ................................................... 116

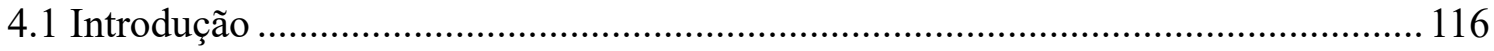

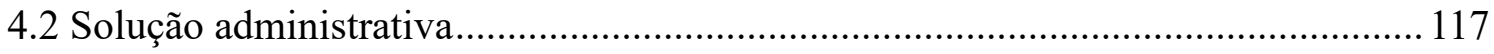

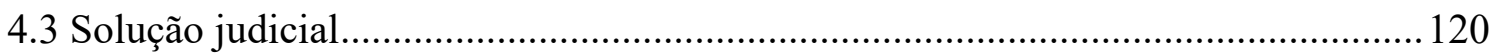

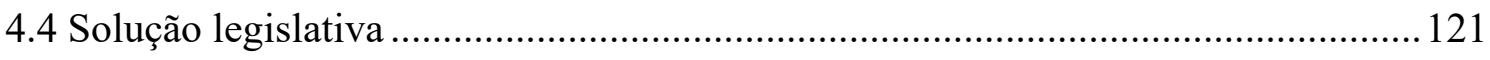

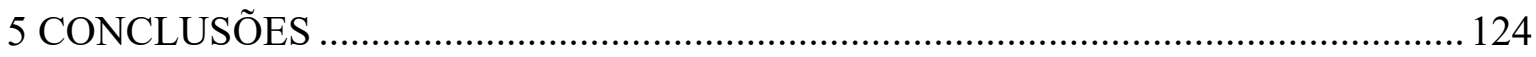

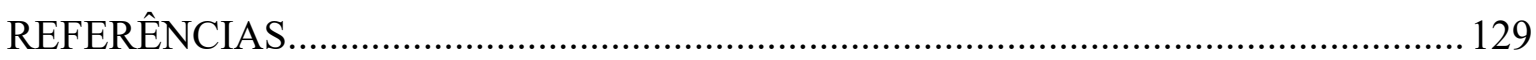

APÊNDICE A - Proposta de Projeto de Lei..................................................................... 136

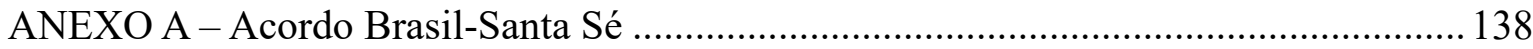




\section{INTRODUÇÃO}

\subsection{A Igreja Católica e o Brasil}

\section{A Igreja Católica Apostólica Romana está intimamente ligada ao Brasil e à sua} história. Na verdade, a Igreja Católica ${ }^{1}$ chegou ao Brasil no dia de seu descobrimento e poder-se-ia afirmar que, sem a Igreja Católica, não teria havido a descoberta de 22 de abril de 1500, ou, pelo menos, ela teria sido sobremaneira diferente, de modo que não conheceríamos o Brasil que hoje existe, da forma que ele existe, se Portugal não tivesse sido, além de todas as coisas, uma nação genuinamente católica e missionária ${ }^{2}$. A partir do evento

\footnotetext{
${ }^{1}$ É importante, logo no início desta Introdução, esclarecermos o que entendemos por "Igreja Católica" e o que queremos dizer ao nos referirmos a ela. Há várias formas de entendermos a "Igreja Católica", tanto do ponto de vista físico como metafísico ou teológico. Neste trabalho, concentrar-nos-emos nas acepções de ordem física, uma vez que nem a metafísica nem a Sagrada Teologia fazem parte de nossos objetivos aqui propostos. O Catecismo Romano do Concílio de Trento, Art. $9^{\circ}, \S 2$, b, define "Igreja" "a comunidade cristã, as reuniões de fiéis, isto é, daqueles que pela fé foram 'convocados' à luz da verdade e ao conhecimento de Deus, que renunciaram [enfim] às trevas da ignorância e do erro, para adorarem pia e santamente o Deus vivo e verdadeiro, e servi-l'O de todo o coração". E, enfim, citando Santo Agostinho, resume: "A Igreja é o povo fiel disseminado pelo mundo inteiro". O novo Catecismo da Igreja Católica mantém a mesma definição. Em seu Parágrafo 752, diz que "Na linguagem cristã, a palavra 'Igreja' designa a assembleia litúrgica, mas também a comunidade local ou toda a comunidade dos crentes. Esses três significados são inseparáveis". Por outro lado, não há que se confundir a Igreja Católica com outras duas figuras a ela relacionadas e que muitas vezes são tomadas por sinônimo: a Santa Sé e o Estado da Cidade do Vaticano. A Santa Sé pode ter duas acepções diferentes, pode ser considerada, em sentido mais amplo, como a Sede Papal e a cúria romana, com todas as suas congregações, prefeituras, tribunais etc. ou, em sentido mais estrito, apenas a figura do Sumo Pontífice, também em seu sentido mais abstrato. Porém, como bem lembra CAMMEO, "la distinzione fra la personalità di Essa [la Santa Sede] e quella della Chiesa non è sempre facile: perché la prima è l'organo direttivo e centrale dell'altra e non sempre si riesce a ben differenziare il capo dalle membra, mentre perfino vi sono casi in cui non si può o non si deve farlo" (CAMMEO, Federico. Ordinamento giuridico dello Stato della Città del Vaticano. Reedição da edição de 1932. Cidade do Vaticano: Libreria Editrice Vaticana, 2005. p. 10-11). Finalmente, o Estado da Cidade do Vaticano é o ente, sujeito de direito internacional, reconhecido Estado desde a assinatura do assim chamado "Tratado de Latão", celebrado em 11 de fevereiro de 1929 entre o Reino da Itália, cujo governo na época era guiado por Benito Mussolini, e a Santa Sé. Em suma e diante da explicação acima, o termo "Igreja Católica" designará aqui a comunidade universal dos fiéis que estão submetidos à hierarquia dos bispos unidos e submetidos, por sua vez, ao Bispo de Roma, o Papa, figura que personifica a Santa Sé.

${ }^{2}$ Não é nossa intenção e nem teríamos espaço suficiente para tratarmos da íntima relação entre a Igreja Católica e o Reino de Portugal. No entanto, cabe dizer que a relação entre as navegações portuguesas e a propagação da fé católica era grande. CARNEIRO afirma que "Todos sabem que os reis de Portugal, como os seus exploradores, estavam convencidos de que com suas viagens, descobrimentos e conquistas não faziam que propagar o catolicismo" (CARNEIRO, Júlio Maria de Morais. O catolicismo no Brasil. Belo Horizonte: Cristo Rei, 2017. p. 35). Nesse mesmo sentido, VIEIRA: “A nação europeia que colonizou o Brasil - Portugal - teve uma história em que as atividades da religião e da política junto ao povo fiel comumente se mesclavam. Ainda no século VIII, os reinos que mais tarde comporiam os dois países ibéricos, no pressuposto de serem portadores da verdadeira fé, concebiam cada nova conquista como parte do engrandecimento do Cristianismo" (VIEIRA, Dilermando Ramos. História do catolicismo no Brasil. Aparecida: Santuário, 2016. p. 9). Para corroborar o fato, citamos também NORONHA: "Em pleno século XII, perfeitamente nos quadros da Respublica Christiana, o primeiro rei de Portugal, Dom Afonso Henriques prestou vassalagem à Igreja. Foi perante o cardeal Guido de Vico que o soberano do novo Reino rendeu suas homenagens. Entende-se, pois nesse momento histórico a independência política de um reino cristão deveria ser ratificada por Roma. Surgiu um
} 
inicial do descobrimento, a presença católica em terras brasileiras foi crescendo e se intensificando, muito em razão das íntimas relações já existentes entre a Igreja Católica e o Reino de Portugal, como será mais bem analisado no decorrer deste trabalho.

Passados mais de quinhentos anos do descobrimento do Brasil a presença católica nestas terras já não é tão pujante como costumava ser, mas, mesmo assim, de acordo com os dados fornecidos pelo Anuário da Igreja Católica no Brasil ${ }^{3}$, em 2012 a Igreja Católica possuía 10.720 paróquias, 22.119 sacerdotes, 2.711 diáconos permanentes, 3.863 irmãos $^{4} \mathrm{e}$ 33.386 irmãs religiosas. Esses são números impressionantes que demonstram uma presença católica ainda grande e importante no Brasil, com crescimento constante, ainda que pequeno, no decorrer dos últimos trinta $\operatorname{anos}^{5}$. A estrutura da Igreja Católica no Brasil não sustenta apenas os templos que utiliza para o desempenho de sua liturgia pública, tampouco somente sua hierarquia, com escritórios, arquivos, bibliotecas, casas de formação, seminários, institutos de vida consagrada etc., mas também controla direta ou indiretamente um semnúmero de hospitais, escolas, orfanatos, casas de repouso etc., o que faz dela, verossimilmente, uma das maiores, se não a maior instituição beneficente do país ${ }^{6}$. Não apenas isso: para manter sua estrutura de assistência material e espiritual, a Igreja Católica administra uma grande quantidade de empresas que vão desde empreendimentos imobiliários até o comércio em geral.

Toda essa estrutura precisa estar obviamente integrada ao ordenamento jurídico brasileiro e funcionar de acordo com suas regras, com efeito, como bem diz RHODE, "sembra difficile immaginare che um ente ecclasiastico possa compiere la sua missione nel

\footnotetext{
vínculo especial entre a Igreja e Portugal" (NORONHA, Ibsen. Incursões jurídico-históricas sobre as relações entre a Igreja Católica e o Brasil - do Descobrimento à Independência. In: BALDISSERI, Lorenzo; MARTINS FILHO, Ives Gandra da Silva (coord.). Acordo Brasil-Santa Sé comentado. São Paulo: LTr, 2012. p. 63-64). É sabido, ainda, que o estandarte carregado pelas velas das naus portuguesas, imortalizado em tantas obras de arte, é aquele da Ordem de Cristo, surgida dos espólios da Ordem do Templo e que foi fundada em Portugal por pedido real e concessão papal em 14 de março de 1319, por meio da bula Ad ea ex quibus, ordem da qual o rei de Portugal tornar-se-ia, inicialmente de facto e, posteriormente, de direito, grão-mestre. Cf. MEDEIROS, José. Usos e cerimônias da nossa Ordem de Cristo. Sintra: Zéfiro, 2008; AMEAL, João. História de Portugal. 4. ed. Porto: Tavares Martins, 1958; PERES, Damião. História de Portugal. Barcelos: Portucalense, 1931. v. II e III; e DIAS, Carlos Malheiros. História da colonização portuguesa do Brasil. Porto: Litografia Nacional, 1923. v. II. Em resumo, o que queremos demonstrar é que, ao contrário do que a historiografia tradicional costuma apontar, a descoberta do Brasil estava inserida em um contexto muito maior do que a simples procura por rotas comerciais para o oriente ou a expansão mercantilista de um império marítimo, o aspecto religioso era tão ou mais importante do que aquele econômico, e esse fator, o religioso, será determinante para a constituição do catolicismo no Brasil, que se tornará marca indelével da nossa nação.

${ }^{3}$ Anuário Católico do Brasil. Rio de Janeiro: Ceris, 2012. v. 13.

${ }^{4}$ Religiosos não sacerdotes.

${ }^{5}$ Op. cit., p. 77 e 78 . O único indicador negativo com relação ao crescimento da Igreja Católica no Brasil até 2012 é do número de religiosas que, de 1990 até 2010, havia sofrido um decréscimo de 10,68\%.

${ }^{6}$ Não encontramos números confiáveis que corroborem esta afirmação, apenas nos deixamos levar pela evidência dos fatos à nossa disposição.
} 
mondo odierno senza avere questa capacità giuridica"7 . No entanto, a Igreja Católica, ao contrário de outras igrejas e demais denominações de natureza religiosa, possui a particularidade de estar organizada de forma hierárquica e juridicamente fundada por meio de um corpo milenar de normas conhecido como Direito Canônico ${ }^{8}$. Portanto, como bem lembra NDI, novamente citando RHODE, qualquer análise da personalidade jurídica de entes eclesiásticos em um determinado ordenamento jurídico deverá levar em consideração o Direito Civil, o Direito Canônico e o "direito concordatário" entre os Estados soberanos e a Santa Sé$^{9}$. Essa é a estrada que tomamos.

\title{
1.2 O Direito Canônico
}

O Direito Canônico estabelece de forma autônoma e completa a organização da Igreja Católica no mundo. Nas palavras do canonista LE TOURNEAU, o Direito Canônico é

\begin{abstract}
um direito de essência religiosa: pretende relações do homem com esse "outro" muito especial que é Deus. Mas não se trata somente das relações individuais de cada homem com a divindade, como também do direito de uma sociedade humana, de um conjunto de pessoas que têm em comum o facto de ser membros da Igreja Católica $^{10}$.
\end{abstract}

\footnotetext{
7 Tradução nossa: "parece difícil imaginar que um ente eclesiástico possa executar a sua missão no mundo atual sem esta capacidade jurídica" (RHODE, Ulrich. La personalità giuridica degli enti ecclesiastici negli ordinamenti civili. Periodica, v. 105, p. 1, 2016. In: NDI, Joseph Clifford N. Contracts between ecclesiastical entities according to canon law. Berlim: Logos, 2018. p. 111).

${ }^{8}$ Utilizaremos o termo "Direito Canônico" neste trabalho para designar o direito da Igreja Católica, ou seja, aquele produzido por meio das fontes de Direito Canônico histórica e legalmente estabelecidas. A este propósito, é importante recordar que as fontes de Direito Canônico são de duas espécies, aquelas de direito divino e as de direito humano. As fontes de direito divino são (i) as Sagradas Escrituras, tanto o Velho quanto o Novo Testamentos (que não são, todavia, considerados no mesmo patamar, mas há uma preponderância hierárquica de importância do segundo desses escritos); e (ii) a Tradição, desde que, porém, seja remetida aos ensinamentos do próprio Cristo, também denominada Tradição Apostólica. Utilizaremos a classificação de CHIAPPETTA, por ser extremamente próxima daquela estabelecida pelo próprio Código de Direito Canônico atual. Assim, CHIAPPETTA estabelece que as normas de direito normativo canônico (direito objetivo) são divididas em duas classes, as fontes de caráter legislativo, que por sua vez são divididas em fontes escritas (cânones 7-22), fontes não escritas (cânones 23-28) e fontes de menor importância (cânones 29-30), e as fontes de caráter administrativo, que por sua vez são divididas entre fontes de ordem geral (cânones 31-34), de ordem singular (cânones 35-93) e de ordem especial (cânones 94-95). Para uma detalhada análise das fontes, recomendamos, CHIAPPETTA, Luigi. Il Codice di Diritto Canonico, commento giuridico-pastorale. 3. ed. Bolonha: Edizione Dehoniane Bologna, 2011. v. I. p. 3.

${ }^{9}$ RHODE, in verbis: "the question about the juridic personality of ecclesiastical entities in civil the law system is a meeting point of diverse juridic legal systems: it is dealt with in the norms of civil law, of Canon Law and of the concordat law, (meaning that by logical connection) attention should be focused on all three areas". In: NDI, op. cit., p. 112.

${ }^{10}$ LE TOURNEAU, Dominique. O Direito da Igreja. Lisboa: Diel, 1998. p. 11-12.
} 
Aqueles que não estão acostumados com sua natureza e aplicação poderiam pensar que o Direito Canônico é algo de estranho à essência daquela que é uma instituição ou uma sociedade cujo escopo é puramente religioso, mas, por outro lado, o mesmo LE TOURNEAU ${ }^{11}$ nos ensina que o poder que deixou Jesus Cristo a seus apóstolos, pessoas às quais confiou seus ensinamentos mais profundos, fazendo deles os primeiros bispos da Igreja que fundou sobre a figura de São Pedro ${ }^{12}$, é um poder de governo (sacra potestas) que pode ser dividido em três outros poderes menores: (i) o poder de ensinar (munus docendi); (ii) o poder de santificar (munus santificandi); e (iii) o poder de governo ou de jurisdição (munus regendi), que, por sua vez, divide-se nas funções legislativa, executiva e judicial ${ }^{13}$.

Possuir um corpo jurídico próprio poderia ser indiferente para fins de integração ao ordenamento jurídico brasileiro, isto é, possuísse ou não a Igreja Católica regras próprias para a aquisição de personalidade jurídica ou para o reconhecimento de capacidade jurídica, não seria um impedimento para que ela constituísse uma pessoa jurídica segundo as regras do Direito brasileiro ou que ganhasse ou perdesse capacidade jurídica dentro dos limites legais do ordenamento pátrio. Com efeito, nenhuma outra denominação religiosa possui um Direito próprio com a complexidade do Direito Canônico e, sem prejuízo disso, possui, por exemplo, pessoas jurídicas de Direito brasileiro a ela ligadas.

\subsection{Colocação do problema e hipóteses de solução}

No entanto, o fato é que a Igreja Católica possui um ordenamento próprio e esse ordenamento é reconhecido atualmente pelo ordenamento jurídico brasileiro, nos termos do Artigo $3^{\circ}$ do Acordo entre o Governo da República Federativa do Brasil e a Santa Sé relativo ao Estatuto Jurídico da Igreja Católica no Brasil, firmado na Cidade do Vaticano, em 13 de

\footnotetext{
${ }^{11}$ Ibidem, p. 17.

${ }^{12}$ As palavras de Cristo que determinam a conferência do poder de fundar e comandar sua Igreja a Pedro são claramente evidenciadas no Evangelho de São Mateus (Mt 16, 18-19): "Et ego dico tibi, quia tu es Petrus, et super hanc petram aedificabo Ecclesiam meam, et portae inferi non praevalebunt adversus eam. Et tibi diabo claves reuni caelorum. Et quodcumque ligaveris super terram, erit ligatum et in caelis: et quodcumque solveris super terram, erit solutum et in caelis" (as citações da Bíblia latina neste trabalho serão retiradas da Biblia Sacra juxta Vulgatam Clementinam. Londres: Baronius Press, 2008. Ela foi publicada como uma edição eletrônica por Michael Tweedale com a aprovação da Conferência Episcopal da Inglaterra e Gales dada em 9 de janeiro de 2006. O texto foi por nós acessado em sua versão impressa, que em português quer dizer: "Também eu te digo que tu és Pedro, e sobre esta pedra edificarei a minha igreja, e as portas do inferno não prevalecerão contra ela. E eu te darei as chaves do reino dos céus. E tudo o que ligares sobre a terra, será ligado também nos céus; e tudo o que desatares sobre a terra será desatado também nos céus" (as citações da Bíblia em português neste trabalho serão retiradas da Bíblia Sagrada. Trad. Padre Antonio Pereira de Figueiredo. Barsa, 1966).

${ }^{13}$ LE TOURNEAU, op. cit., p. 17.
} 
novembro de 2008 e promulgado no Brasil pelo Decreto n. 7.107, de 11 de fevereiro de $2010^{14}$. Esse reconhecimento confere algo de único para a Igreja Católica no Brasil, o fato de que o Direito Canônico é reconhecido e aplicado automaticamente no Brasil, respeitados, como recita o já mencionado Artigo 3 ", "o sistema constitucional e as leis brasileiras" 15 .

Com efeito, respeitado o "sistema constitucional e as leis brasileiras", a única formalidade necessária para o reconhecimento de pessoas jurídicas de Direito Canônico no ordenamento jurídico brasileiro é (ou deveria ser) o registro, no respectivo órgão competente, do ato de criação dessa pessoa jurídica, nos termos do $\S 2^{\circ}$ do já mencionado Artigo $3^{\circ}$ do Acordo Brasil-Santa Sé ${ }^{16}$. Assim, atendidas essas formalidades, o $\S 1^{\circ}$ do mesmo artigo afirma, in verbis, que "A Igreja Católica pode livremente criar, modificar ou extinguir todas as Instituições Eclesiásticas mencionadas no caput deste artigo”.

O fato de o Direito Canônico ser reconhecido pelo Direito brasileiro e poder, autonomamente, criar e modificar pessoas jurídicas reconhecidas no Brasil cria uma situação peculiar e única em nosso ordenamento para uma organização de cunho religioso. No entanto, na prática, ainda há muita confusão no momento em que as pessoas jurídicas de Direito Canônico precisam se transformar também em pessoas jurídicas de Direito brasileiro, nos termos da legislação existente já mencionada acima. De acordo com dados e relatos que mencionaremos neste trabalho, veremos como paróquias ainda têm dificuldades para abrir simples contas bancárias e dependem muitas vezes de outras pessoas jurídicas (uma diocese, por exemplo) que já conseguiram ter seu reconhecimento anterior pelo Direito brasileiro. Ainda, temos notícias de casos em que a imunidade tributária constitucional concedida a entes religiosos ${ }^{17}$ não é respeitada, seja por falta de conhecimento, seja por deliberada

\footnotetext{
${ }^{14}$ Este acordo será, daqui em diante, referido neste trabalho como "Acordo Brasil-Santa Sé".

${ }^{15}$ A celebração do Acordo Brasil-Santa Sé gerou inclusive protestos de algumas denominações protestantes que chegaram, como no caso dos metodistas, a apelar para que o Senado Federal não ratificasse a assinatura do Acordo. Vide, por exemplo: GOSPEL+. Protestantes questionam acordo com Igreja Católica. 17 mar. 2009. Disponível em: https://noticias.gospelmais.com.br/protestantes-questionam-acordo-com-igreja-catolica.html. Acesso em: 11 jan. 2020; e LOPES, João Carlos. Pronunciamento do colégio episcopal sobre acordo BrasilVaticano. Portal Nacional da Igreja Metodista. 13 set. 2013. Disponível em: http://www.metodista.org.br/pronunciamento-do-colegio-episcopal-sobre-acordo-brasil-vaticano. Acesso em: 11 jan. 2020.

16 “§ $2^{\circ}$ A personalidade jurídica das Instituições Eclesiásticas será reconhecida pela República Federativa do Brasil mediante a inscrição no respectivo registro do ato de criação, nos termos da legislação brasileira, vedado ao poder público negar-lhes reconhecimento ou registro do ato de criação, devendo também ser averbadas todas as alterações por que passar o ato."

17 “Art. 150. Sem prejuízo de outras garantias asseguradas ao contribuinte, é vedado à União, aos Estados, ao Distrito Federal e aos Municípios:

(...)

VI - instituir impostos sobre:

(...)
} 
intenção de autoridades públicas em desconsiderar o Direito vigente. Com isso, buscaremos demonstrar que, do ponto de vista fático, há um problema no reconhecimento das pessoas de Direito Canônico no ordenamento civil brasileiro decorrente principalmente (i) da falta de clareza na definição de qual seja a natureza jurídica das pessoas jurídicas de Direito Canônico dentro do ordenamento civil brasileiro ${ }^{18}$; e (ii) de determinadas lacunas do Direito vigente aplicável ao tema.

Analisaremos a seguir, de forma introdutória, o primeiro problema apontado, ou seja, a falta de clareza na definição da natureza das pessoas jurídicas de Direito Canônico dentro do ordenamento civil brasileiro. Apontar a natureza de um instituto jurídico é de vital importância para delimitar seu alcance e, daí, tirarmos as consequências, ou seja, aplicá-lo na prática. No caso específico do tema tratado, nosso objeto (as pessoas jurídicas de Direito Canônico) possui uma natureza dentro de seu ordenamento original, ou seja, pode ser, por exemplo, dioceses ${ }^{19}$, paróquias $^{20}$, institutos de vida consagrada ${ }^{21}$, prelazias pessoais ${ }^{22}$ etc. Todos esses institutos possuem uma natureza própria e claramente definida no âmbito do Direito Canônico. Porém uma vez que, por força de lei, conforme o Acordo Brasil-Santa Sé, tais pessoas jurídicas adentram o ordenamento da República Federativa do Brasil, conservarão elas a mesma natureza? O ordenamento jurídico brasileiro conhece as associações $^{23}$, as fundações ${ }^{24}$, diversos tipos de sociedade ${ }^{25}$, reconhece atualmente inclusive empresas individuais de responsabilidade $\operatorname{limitada}^{26}$, mas não há qualquer coincidência entre as pessoas jurídicas de Direito Canônico que mencionamos e aquelas de Direito Civil brasileiro. A clara definição da natureza jurídica de um ente é absolutamente relevante para que o aplicador do Direito saiba quais as regras aplicáveis a esse instituto. Será tendo a clara identificação de que um ente de Direito Canônico pertente à categoria jurídica “A” ou "B" que, por exemplo, um registrador aceitará seus atos constitutivos e o registrará como ente

\footnotetext{
b) templos de qualquer culto;

(...)

$\S 4^{\circ}$ As vedações expressas no inciso VI, alíneas $b$ e $c$, compreendem somente o patrimônio, a renda e os serviços, relacionados com as finalidades essenciais das entidades nelas mencionadas."

${ }^{18}$ Sem a definição da natureza jurídica de um ente, é difícil que ele consiga executar os atos da vida civil que são essenciais para sua existência. Com efeito, NDI diz: "technically, it is in asserting the civil juridic status of the ecclesiastical entity that it (the ecclesiastical entity) becomes more apparent as a legally qualified party to a contract" (NDI, op. cit., p. 111).

${ }^{19}$ Cânon 369 do CDC.

${ }^{20}$ Cânon 515, § 1, do CDC.

${ }^{21}$ Cânon 573, § 2, do CDC.

${ }^{22}$ Cânon 294 do CDC.

${ }^{23}$ Artigo 53 do Código Civil.

${ }^{24}$ Artigo 62 do Código Civil.

${ }^{25}$ Artigos 981 e seguintes do Código Civil.

${ }^{26}$ Artigo 980-A do Código Civil.
} 
jurídico "A" ou "B", ou, ainda, dirá que, por ser uma categoria "CC, esse ente não deverá sofrer o registro naquele órgão, mas em outro.

Dessa forma, ao analisarmos as pessoas jurídicas de Direito Canônico, a questão primordial que deve ser respondida é justamente a natureza desses entes dentro do ordenamento civil brasileiro, à luz do Direito vigente. Assim, entendemos que, necessariamente, a resposta quanto à natureza desses entes deverá ser incluída em uma de três opções: (i) ou essas pessoas jurídicas conservam sua natureza jurídica original, ou seja, o ordenamento brasileiro que, como vimos, possui um rol fechado de pessoas jurídicas admitidas, passaria a incorporar ao seu ordenamento também aquelas de Direito Canônico, de forma que deveríamos considerar que, ao lado das associações e sociedades, por exemplo, haveria as dioceses, as paróquias, as prelazias etc.; (ii) ou as pessoas jurídicas de Direito Canônico adotariam, uma vez admitidas dentro do ordenamento civil brasileiro, a natureza jurídica de uma daquelas opções dadas pelo legislador pátrio. Nesse caso, ou a lei deveria dizer qual pessoa jurídica de Direito Canônico corresponde a qual pessoa jurídica de Direito Civil brasileiro, o que, adiantamos, não o faz, ou dever-se-ia utilizar a analogia para podermos adequar as pessoas jurídicas brasileiras àquelas canônicas, como, por exemplo, considerar que uma paróquia seria uma "espécie de associação" 27 ; (iii) ou, finalmente, as pessoas jurídicas de Direito Canônico seriam consideradas como um ente sui generis, ou seja, elas não poderiam preservar sua natureza original uma vez aceitas em nosso ordenamento, mas, por outro lado, conservariam algumas das características necessárias de sua natureza original. Da mesma forma, as pessoas jurídicas canônicas não deveriam ser “encaixadas" dentro dos tipos de pessoas jurídicas existentes no Direito Civil brasileiro, mas, possivelmente, iriam ter que se adaptar, de alguma forma, ao ordenamento dentro do qual terão sua existência jurídica.

Conforme veremos adiante, nenhuma das três opções possíveis é plenamente satisfatória para todas as partes consideradas, sendo, no entanto, aceitável apenas uma, dentro do estado atual da legislação brasileira e considerando aqui inclusive o Acordo BrasilSanta Sé. Considerar que as pessoas jurídicas de Direito Canônico mantêm sua mesma natureza jurídica ao entrar no ordenamento jurídico brasileiro seria talvez uma solução extremamente benéfica e confortável para a Igreja Católica, mas equivaleria, na prática, a aceitar que um ente de Direito Internacional Público teria o poder de alterar, de forma

${ }^{27}$ Por mais esdrúxula que possa parecer essa solução, na prática, é assim que muitas autoridades públicas e privadas acabam considerando as pessoas jurídicas de Direito Canônico quando são desafiadas a terem que lidar com elas. 
unilateral, o ordenamento civil brasileiro e isso, mesmo que "não contrariasse o sistema constitucional e as leis brasileiras", como pede o caput do Artigo $3^{\circ}$ do Acordo Brasil-Santa Sé, seria, do ponto de vista da soberania nacional, inaceitável ${ }^{28}$. Por outro lado, exigir que uma pessoa jurídica de Direito Canônico fosse "encaixada" em uma das categorias de pessoas jurídicas existentes no Direito Civil brasileiro, ao contrário da primeira opção, poderia restringir sobremaneira a possibilidade de atuação e exercício das atividades das pessoas jurídicas canônicas, uma vez que as forçaria a obedecer regras que não lhes são próprias, contrariando assim o próprio Acordo Brasil-Santa Sé, em que o Brasil "reconhece à Igreja Católica o direito de desempenhar a sua missão apostólica, garantindo o exercício público de suas atividades" ${ }^{29}$. Dessa forma, consideramos que a segunda opção, para a Igreja Católica, seria inaceitável. Finalmente, resta-nos assim a terceira opção, ou seja, considerar as pessoas jurídicas de Direito Canônico como entes sui generis.

O termo sui generis significa, literalmente, “único em seu gênero" e, em Direito, é utilizado para designar institutos ou entes jurídicos de natureza própria e sem comparação no ordenamento ${ }^{30}$. Ser um ente sui generis no caso das pessoas jurídicas de Direito Canônico indicaria, portanto, duas realidades: (i) que tais entes não conservariam, portanto, nem suas características originais e nem características típicas de pessoas jurídicas de Direito brasileiro; e (ii) que não há, no ordenamento civil brasileiro, nenhuma outra figura jurídica com esse mesmo status. No caso das pessoas jurídicas de Direito Canônico, sustentaremos aqui que após o Acordo Brasil-Santa Sé ambas essas afirmações são verdadeiras. Com essa terceira solução, aparentemente todos os problemas criados pelas outras duas possibilidades mencionadas acima seriam resolvidos, pois um ente sui generis não está preso às categorias jurídicas preexistentes no ordenamento brasileiro e nem, por outro lado, seria impedido de entrar nesse mesmo ordenamento por manter determinadas características de sua natureza originária.

Há, no entanto, problemas que derivam do fato de considerarmos as pessoas jurídicas de Direito Canônico entes sui generis em nosso ordenamento. Justamente por ser algo

\footnotetext{
${ }^{28}$ Segundo BROWNLIE, "o termo 'soberania' pode ser utilizado como sinônimo de independência, um elemento importante da qualidade de Estado já considerado. No entanto, uma origem comum de confusão reside no fato de a 'soberania' poder ser utilizada para descrever a condição na qual um Estado não tenha exercido as suas próprias capacidades jurídicas de modo a criar direitos, poderes, privilégios e imunidades em relação a outros Estados. Neste sentido, um Estado que consentiu que outro Estado gerisse as suas relações externas, ou que concedeu vastos direitos extraterritoriais a outro Estado, não é 'soberano"' (BROWNLIE, Ian. Princípios de Direito Internacional Público. 4. ed. Lisboa: Fundação Calouste Gulbenkian, 1990. p. 90).

${ }^{29}$ Artigo $2^{\circ}$ do Acordo Brasil-Santa Sé.

${ }^{30}$ Pensemos, por exemplo, nos contratos inominados, ou seja, aqueles tipos contratuais que não estão previstos e nominados explicitamente no Código Civil, mas que nem por isso deixam de ter guarida e produzir efeitos jurídicos em nosso ordenamento.
} 
diverso daquilo que já existe, seria necessário, além de uma definição clara de sua natureza, a definição também de um arcabouço legal que desse o suporte necessário a essa situação especial, justamente para que não ocorram confusões e para que o Direito, tanto brasileiro quanto aquele da Igreja Católica, não seja lesado.

O Código Civil proclama, em seu artigo 44, que, dentre o rol de pessoas jurídicas de Direito Privado reconhecidas pelo nosso ordenamento civil estão, no inciso IV, as "organizações religiosas". Além disso, o $§ 1^{\circ}$ desse mesmo artigo 44 estabelece que "são livres a criação, a organização, a estruturação interna e o funcionamento das organizações religiosas, sendo vedado ao poder público negar-lhes reconhecimento ou registro dos atos constitutivos e necessários ao seu funcionamento". Ambas as redações foram adicionadas ao Código Civil por meio da Lei n. 10.824, de 22 de dezembro de 2003, justamente para tentar mitigar a confusão jurídica que havia desde a promulgação do Código Civil (e antes) com relação à natureza jurídica de qualquer estrutura jurídica ligada a entidades religiosas. Com efeito, antes do Código Civil de 2002, os problemas para o reconhecimento da personalidade jurídica das pessoas jurídicas de Direito Canônico eram tão crônicos a ponto de o Dicionário de Direito Canônico, de 1997, afirmar que "no campo civil, a personalidade das paróquias não é reconhecida pela legislação brasileira. Por isso é comum inscrevê-las como filiais da Mitra diocesana, esta sim reconhecida, em virtude do art. $5^{\circ}$ do Decreto $n$. 119-A, de $1890^{31}$ ". Por outro lado, mesmo após a promulgação da citada Lei n. 10.824/2003, os problemas continuaram os mesmos, como se pode depreender do parecer do ConsultorGeral da República preparado em 2005 sobre o tema, justamente a pedido da Conferência Nacional dos Bispos do Brasil (CNBB), para solucionar dúvidas oriundas da natureza da personalidade jurídica da Igreja no Brasil: “o fato porém é que, como narra a CNBB, atualmente, tanto as dioceses como as paróquias vêm tendo dificuldade de participar de negócios jurídicos, à falta de se lhes reconhecer personalidade jurídica" ${ }^{32}$. A verdade é que o reconhecimento do Código Civil às “organizações religiosas" parece demasiado amplo, o que, se por um lado poderia parecer bom para essas organizações pois the daria ampla margem para suas atividades, por outro, simplesmente não parece aplicável na realidade. Em

\footnotetext{
${ }^{31}$ Cf. Paróquia [verbete]. In: SALVADOR, C. Corral; EMBIL, J. M. Urteaga. Dicionário de Direito Canônico. São Paulo: Loyola, 1997. Apud: SPRIZZI, Marco. Art. $3^{\circ}$ Personalidade jurídica. In: BALDISSERI, Lorenzo; MARTINS FILHO, Ives Gandra da Silva (coord.). Acordo Brasil-Santa Sé comentado. São Paulo: LTr, 2012. p. 155.

${ }^{32}$ Consultor-Geral da União - Parecer AGU/MP n. 16/2005 e respectivo Despacho n. 34/2006, aprovado pelo Advogado-Geral da União em 28 de agosto de 2006, p. 5. Apud: SPRIZZI, op. cit., p. 155.
} 
poucas palavras, o que são "organizações religiosas" 33 ? E, ainda, quais são os registros e as formalidades necessárias para que essas pessoas passem a existir?

Dessa forma, diante dos problemas que continuavam a ser verificados, a forma que as partes (Santa Sé e República Federativa do Brasil) encontraram para resolver de uma vez por todas as dúvidas que pairavam sobre o tema foi a assinatura do Acordo Brasil-Santa Sé. Nesse sentido, SPRIZZI chega a afirmar que o já citado Artigo $3^{\circ}$ do Acordo Brasil-Santa Sé, que trata da personalidade jurídica de pessoas de Direito Canônico, é "o núcleo fundamental e razão basilar da estipulação do Tratado" (grifos do autor original) ${ }^{34}$. A opinião de SPRIZZI é muito importante, seja pelo fato de ele ser perito canonista da Nunciatura Apostólica no Brasil na época da assinatura do documento, com conhecimento de causa, portanto, seja pelo fato de explicitar a gravidade dos problemas encontrados antes.

A redação do Artigo $3^{\circ}$ do Acordo Brasil-Santa Sé responde à primeira parte dos problemas encontrados pela Igreja Católica e pelos aplicadores do Direito pátrio, ou seja, a definição da natureza jurídica dos entes de Direito Canônico em nosso ordenamento. Agora o tratado deixa claro que a personalidade jurídica da Igreja Católica e de todas as Instituições Eclesiásticas que possuem tal personalidade em conformidade com o Direito Canônico, é reafirmada, porém, desde que não contrarie o sistema constitucional e as leis brasileiras, o que poderá comportar alguma modificação nos atos constitutivos de tais entes e dará a eles o caráter sui generis conforme apontado acima. Porém, o texto do $\S 2^{\circ}$ do Artigo $3^{\circ}$, que trata do registro dessas pessoas jurídicas, não esclarece quais os procedimentos necessários para que essas pessoas entrem no ordenamento brasileiro, quase repetindo a mesma redação do Código Civil de que o poder público não pode negar reconhecimento ou registro a tais entes, mas não dizendo quais entes do poder público e nem quais registros deveriam realizar. Entendemos e concordamos que esse tipo de minúcia não é competência de um tratado internacional curto e de difícil negociação como foi o Acordo Brasil-Santa Sé, porém, uma vez que o tratado existe, teria cabido ao Brasil criar legislação que completasse e desse eficácia ao quanto estabelecido pelas partes contratantes do acordo. Da forma como nos encontramos hoje, do ponto de vista legislativo, não há muita diferença com relação à

\footnotetext{
${ }^{33}$ Sintomática da posição dominante entre os juristas e aplicadores do Direito no Brasil, a posição do professor Nestor DUARTE que, ao comentar o artigo 44 do Código Civil, explica que "aquelas [as organizações religiosas] e estes [os partidos políticos], muito se aproximam das associações, por terem finalidades não econômicas e se sustentarem na organização de pessoas" (DUARTE, Nestor. Comentário ao artigo 44 do Código Civil. Código Civil comentado: doutrina e jurisprudência. Manole, São Paulo, 2007. p. 45).

${ }^{34}$ SPRIZZI, op. cit., p. 138.
} 
situação pré-Acordo Brasil-Santa Sé; assim, além de problemas de clareza, temos também, como mencionado acima, lacunas legislativas que deveriam ser resolvidas.

\subsection{Hipótese metodológica}

Finalmente, tendo analisado o problema que existe hoje e identificado quais são suas causas e possíveis soluções, resta-nos voltar ao início desta Introdução e nos questionar: mas se a presença católica no Brasil é tão antiga quanto o próprio Brasil, por que nos encontramos no final da segunda década do século XXI com problemas de definição e gozo de direitos de pessoas jurídicas de Direito Canônico? Esses entes não estiveram sempre presentes no Brasil? Como foi que nossos antepassados trataram essa mesma questão nos séculos passados? As soluções que encontraram foram mais ou menos eficazes do que esta que produzimos hoje com nosso marco legal? O recurso à história do Direito deverá nos auxiliar a responder a essas questões.

Nas palavras de GILISSEN, “a história do direito visa a fazer compreender como é que o direito actual se formou e desenvolveu, bem como de que maneira evoluiu no decurso dos séculos" ${ }^{35}$. É justamente este o trabalho que nos propomos a realizar na parte maior da nossa dissertação de mestrado, ou seja, investigar no passado legislativo brasileiro quais eram as soluções dadas a esse problema atual de definição da personalidade jurídica das pessoas de Direito Canônico. Obviamente precisaremos recorrer com frequência às fontes históricas jurídicas; e não só, pois será necessário entender como era o relacionamento institucional entre o Brasil (ou o Reino de Portugal, quando aplicável) e a Santa Sé. Sabemos que o Direito Canônico existe antes de o Brasil existir. Na verdade, o Direito Canônico existe antes mesmo de Portugal ou qualquer outro país que conhecemos hoje existir, portanto, precisaremos entender se qualquer comparação entre instituições que não existem mais (como, por exemplo, o próprio Reino de Portugal e o Império brasileiro, assim como institutos como o padroado) e o Brasil moderno é cabível e se pode, na prática, gerar resultados aplicáveis à realidade tal qual ela se apresenta neste momento.

Com a análise histórica da situação jurídica da Igreja Católica no Brasil, desde o momento em que se iniciou nossa história em 22 de abril de 1500 até os momentos que antecederam a assinatura do Acordo Brasil-Santa Sé, poderemos analisar as mudanças ocorridas na forma como o Estado brasileiro (ou português, conforme o caso) tratou a Igreja

${ }^{35}$ GILISSEN, John. Introdução histórica ao Direito. 2. ed. Lisboa: Fundação Calouste Gulbenkian, 1995. p. 13. 
Católica e deu respaldo às suas atividades em terras brasileiras. De posse desse material, poderemos compará-lo à situação atual, conforme delineado acima e que será mais bem detalhada neste nosso trabalho, de modo que, ao final de nossa dissertação, esperamos poder concluir com um juízo sobre a situação atual da Igreja Católica no Brasil, quanto à personalidade jurídica dos entes de Direito Canônico, sugerindo eventuais alterações ou correções de rota baseando-nos na realidade tal qual nos é apresentada hoje, mas com a bagagem histórica a nos fornecer a experiência daquilo que deu certo contra aquilo que poderá ser esquecido, porque já se demonstrou ineficaz. 


\section{CONCLUSÕES}

Nas páginas precedentes tentamos passar em revista mais de quinhentos anos de história brasileira para entendermos como as pessoas jurídicas de Direito Canônico foram tratadas no ordenamento pátrio desde a chegada de Cabral até nossos dias. Para realizarmos essa tarefa, tivemos que olhar para ainda mais longe do que 1500, uma vez que, para entender o estado do Direito português e daquele canônico, bases iniciais de nossa pesquisa, precisávamos ver de onde ambos tinham vindo e qual seu estado, sobretudo no que concerne às pessoas jurídicas de Direito Canônico, antes do fatídico 22 de abril de 1500. O objetivo foi, por meio dessa investigação histórico-jurídica, colher as bases do passado para entender o presente e averiguar se era possível, com o auxílio das lições do passado, sugerir modificações para melhorar os problemas que encontramos no presente e evitá-los no futuro.

Em nossa investigação passamos por um período, o primeiro deles, desde a formação do Reino de Portugal até a Lei da Boa Razão, em que o Direito Canônico foi parte integrante do Direito português, integrando-o, alterando-o e, sobretudo, servindo de base moral objetiva para nortear todo o ordenamento, dando assim coerência e segurança para o sistema. As relações entre o Reino e a Igreja nem sempre foram harmônicas nesse período, como mostramos detalhadamente nesta dissertação, porém essa união profunda entre as culturas jurídicas produziu um dos maiores impérios que o mundo já viu, que resplandeceu no globo e levou a cultura lusitana e o Evangelho a povos longínquos, com inegáveis benefícios a estes últimos. Particularmente no Brasil, esse período, que podemos chamar de "colonial", foi aquele que produziu o início da civilização brasileira, cuja responsabilidade é, inegavelmente, da Igreja Católica, na figura de missionários, em sua maioria jesuítas, que dedicaram a vida (muitas vezes até o ponto de perdê-la) para evangelizar a nova terra. Esse foi o período de maior harmonia nas relações Igreja-Estado no Brasil e, sustentamos, não coincidentemente, foi quando a música, a escultura, a arquitetura e a urbanização, dentre outros aspectos civilizacionais, alcançaram níveis que até hoje não foi mais possível repetir. A decadência dessa relação especial iniciou com o Humanismo e a mudança de perspectiva do homem europeu, antes teocêntrica, para um individualismo sempre mais destacado. $\mathrm{O}$ Humanismo, o absolutismo monárquico e o fato político da União Ibérica ajudaram a minar em grande parte a harmonia e o equilíbrio antes existentes. Assim, foi fácil para o racionalismo iluminista, representado em Portugal, principalmente, pela figura do Marquês 
de Pombal, excluir de uma vez por todas a Igreja e o Direito Canônico do ordenamento português.

O segundo período, já completamente "brasileiro", é aquele iniciado pelo "Grito do Ipiranga", ou seja, o chamado período "imperial". Nesse período, o Estado e a Igreja continuavam unidos, mas por amarras forçadas criadas por apenas uma das partes, que se apropriou de um direito que não lhe fora outorgado e fazia dele mau uso, para diminuir, humilhar e sufocar a Igreja no Brasil. Durante esse período, as novas vocações religiosas foram proibidas com o fechamento dos noviciados e os níveis intelectual e moral do clero caíram muito, visto que muitos se sentiam mais funcionários públicos do que sacerdotes unidos ao papa. Sem prejuízo disso, o Direito Canônico continuava, mesmo que de forma indireta, a produzir direito em nosso ordenamento, e as pessoas jurídicas, quando reconhecidas e quando as amarras legais permitiam, tinham facilidade de representação, sem que precisassem ser equiparadas a outras figuras do Direito pátrio ou sofrer mutilações de qualquer natureza. Assim, este é um período prenhe de lições para tirarmos. Por um lado, vemos como a união Estado-Igreja, quando mal aplicada, sobretudo na sua vertente de submissão da Igreja ao Estado, pode produzir o sufocamento e quase morte da Igreja, que não conseguirá exercer sua missão. Por outro lado, o ordenamento jurídico não tinha problemas em dar aos entes eclesiásticos os direitos de serem representados "na forma de seus estatutos" e por seus representantes legais na forma do Direito Canônico. Este é um ponto que pode ser reaproveitado em nossos tempos para facilitar o exercício de direitos e obrigações e a celebração de negócios jurídicos e outros atos pelos entes eclesiásticos.

O terceiro período é aquele iniciado em 15 de novembro de 1889, o "republicano", marcado pela separação entre Igreja e Estado e um esboçar-se de anticlericalismo, mas que depois acabou se tornando indiferentismo. Este é o período no qual a Igreja precisou encontrar seus espaços em um ambiente onde não mais contava com a proteção do Estado, mas que, por outro lado, tinha plena liberdade de atuação. Não por acaso, a primeira metade do século XX viu a Igreja no Brasil crescer, com o florescimento de vocações e a expansão do ensino e da presença geral da Igreja na vida pública brasileira. Por outro lado, este é o período no qual os germes dos problemas atuais começam a brotar. Isso porque o Código Civil de 1916 trazia uma linguagem pouco clara quanto à personalidade jurídica das pessoas de Direito Canônico, assim como a legislação sobre o tema era esparsa e sem sistematização. No entanto, tratava-se ainda de um país majoritariamente católico, onde muitos dos registradores, juízes e até mesmo políticos que tinham de lidar com a situação eram católicos e entendiam as necessidades da Igreja. Do mesmo modo, a confusão com outras 
"organizações religiosas" também era muito menor. Como lições desse período, podemos aprender que em um ambiente de indiferentismo com relação à Igreja, mas com ampla liberdade de atuação, a Igreja soube sobreviver e exercer sua missão. Porém, a precariedade legal sobre a qual teve de operar fez com que muitas vezes essa liberdade estivesse em risco, como durante as ditaduras de Vargas e aquela militar. Essas ocasiões demonstram como a Igreja não pode se contentar em ter liberdade por ausência de normas que a proíbam de exercer seu ministério ou por complacência de magistrados e funcionários públicos, mas precisa, ao contrário, sempre que possível, esforçar-se para ter um marco legal claro e sólido, sem precariedades, que preserve seus direitos.

O quarto e último período analisado, que é este onde nos encontramos, é caracterizado pela multiplicidade de confissões religiosas no Brasil ${ }^{311}$, todas elas com suas próprias organizações e pessoas jurídicas, pela drástica redução do número de católicos ${ }^{312} \mathrm{e}$ a consequente perda da capacidade de influência que o catolicismo antes tinha nas instituições brasileiras. Dentro desse contexto, a situação que se tinha anteriormente se agravou, pois o marco legislativo não havia sido alterado e, quando o foi, com a Constituição de 1988 e o Código Civil de 2002, as pessoas jurídicas de Direito Canônico viram-se em um ambiente onde haviam perdido um pouco da relevância social e, consequentemente, dos políticos responsáveis por legislar ${ }^{313}$. A miríade de "organizações religiosas" também fazia com que os entes católicos fossem vistos como "uns dentre tantos" que certamente não tinham as mesmas características do Direito Canônico. Esse foi o momento em que a Igreja

${ }^{311}$ IBGE. Censo 2010. Disponível em: https://cidades.ibge.gov.br/brasil/pesquisa/23/22107. Acesso em: 8 nov. 2019.

312 Se considerarmos aqueles "praticantes", esse número de católicos é ainda menor. Para corroborar essa afirmação, citamos ANTONIAZZI: "sabia-se que os católicos eram cerca de $99 \%$ da população no censo de 1890 ( $1 \%$ era de evangélicos e $0,1 \%$ de outras religiões). Em 1950, os católicos eram 93,5\%, os evangélicos 3,4\%. Depois os católicos foram diminuindo (91,8\% em 1970;88,9\% em 1980;83,0\% em 1991; 73,6\% em 2000), e os evangélicos foram aumentando (5,2\% em 1970; 6,7\% em 1980; 10\% em 1991. Além dos dois grupos majoritários (que somam 89\% da população), em 2000 temos 7,3\% que se declaram sem religião; 1,7\% de religiões mediúnicas; $1,6 \%$ de outras religiões e $0,4 \%$ sem informação" (ANTONIAZZI, Alberto. A CNBB e a pastoral urbana; primeiros passos. In: MATOS, Henrique Cristiano José. Nossa História, 500 anos de presença da Igreja Católica no Brasil. São Paulo: Paulinas, 2011. t. 3. p. 262-263).

313 Neste ponto, cabe uma reflexão bastante interessante. De 1891 a 1988, o Brasil teve sete Cartas constitucionais (consideramos que a Emenda Constitucional n. 1, de 17 de outubro de 1969, tratou-se, para todos os efeitos, de uma nova Constituição) e, nesse período, como visto detidamente nesta dissertação, a condição das pessoas jurídicas de Direito Canônico não foi substancialmente alterada. Isso se deu porque a regulamentação dessas pessoas ocorreu, majoritariamente, em nível civil e não constitucional, como havia acontecido, por exemplo, com a Constituição de 1824 e, de forma menos explícita, naquelas de 1891 e 1934 , que reconheciam a personalidade jurídica de "associações religiosas", mas não davam maiores detalhes, e as outras Constituições a partir da "Polaca" já nem se preocupavam em tratar da personalidade jurídica de entidades religiosas. Tal se deu muito em razão de o Código Civil de 1916 tratar do tema. Como esse diploma ficou em vigor por quase noventa anos, não obstante o grande número de Constituições que tivemos, o marco legal aplicável não foi alterado, resultando em estabilidade, mesmo que precária, da condição jurídica de entes eclesiásticos em geral no Brasil. 
buscou o governo do Brasil para tentar um acordo que resolvesse esses e outros problemas de uma vez por todas, dando à Igreja Católica o status especial que havia sempre sido buscado por ela desde o fim do Império. Entendemos que o Acordo Brasil-Santa Sé, resultado prático desses esforços, resolveu, na teoria, os problemas de reconhecimento da personalidade jurídica dos entes de Direito Canônico, mas na prática ainda faltam alguns ajustes para que a vontade das partes contratantes do tratado seja plenamente atendida.

Isso porque, no âmbito das pessoas jurídicas de Direito Canônico tal como tratadas pelo Direito brasileiro, os problemas com os quais nos deparamos são de ordem eminentemente prática, ou seja, de conversas com sacerdotes e religiosos que precisam todos os dias realizar negócios jurídicos dentro do ordenamento brasileiro com suas paróquias, mosteiros, conventos e outros, percebemos que as pessoas jurídicas que se originam do Direito Canônico, ou seja, que, antes de terem eficácia no nosso direito, tiveram sua personalidade dada por esse corpo de leis milenar que é o Direito Canônico, não conseguiam a proteção necessária, com prejuízo para esses próprios entes, para a Igreja Católica e, por que não, para o próprio Brasil, pois, uma vez que ficou clara a intenção do legislador brasileiro em dar guarida para a Igreja Católica em nosso país, reconhecendo explicitamente as pessoas jurídicas de Direito Canônico por meio do Acordo Brasil-Santa Sé, se essa lei não consegue ser eficaz na prática, quer dizer que, em última análise, a vontade do legislador, portanto do povo, não está sendo respeitada, o que merece, sem sombra de dúvidas, uma ação para corrigir suas falhas. Conforme visto acima, ao tratarmos da Lei de Registros Públicos, há um claro entrave ao exercício do direito das pessoas jurídicas de Direito Canônico de serem registradas no Brasil, qual seja, a possibilidade de um controle por parte do registrador que não atende a requisitos objetivos e corre o risco (e na prática o tem feito) de prevenir o registro de tais entes.

Como forma de solucionar esses problemas, no capítulo 4 desta dissertação apresentamos algumas sugestões dentro do nosso ordenamento que, se implementadas, acreditamos, irão de uma vez por todas dar a efetividade necessária ao Acordo Brasil-Santa Sé e resolverão, finalmente, o problema de incertezas jurídicas sofrido pelas pessoas jurídicas de Direito Canônico desde a Proclamação da República.

Esperamos com este trabalho ter jogado algumas luzes no pouco estudado tema das pessoas jurídicas de Direito Canônico na história jurídica brasileira e ter contribuído para um debate que precisa ser aprofundado, para que, com a ajuda das lições do passado, possamos contribuir com a estabilização jurídica desses entes que tanta importância tiveram e ainda têm na história e na vida do Brasil e dos brasileiros. Cremos firmemente que a 
civilização destas terras se deve ao amor incalculável de homens e mulheres consagrados que aqui vieram para pregar e ensinar, e, todas as vezes em que tivemos uma Igreja forte, fomos uma civilização florescente. $\mathrm{O}$ aumento da liberdade e da proteção jurídica à Igreja Católica será necessariamente em prol de todos os brasileiros. 


\section{REFERÊNCIAS}

AGUILLAR, Rafael Salomão Safe Romano. A personalidade jurídica da Igreja no Brasil: do padroado ao Acordo Brasil-Santa Sé. São Paulo: LTr, 2015.

ALMEIDA, Candido Mendes. Direito Civil ecclesiástico brazileiro antigo e moderno em suas relações com o Direito Canônico. Rio de Janeiro: Garnier, 1866.

ALMEIDA, Fortunato. História da Igreja em Portugal. Coimbra: Imprensa Acadêmica, 1910. v. II.

ALVES, Francisco de Assis. Associações, sociedades e fundações no Código Civil de 2002: perfil e adaptações. São Paulo: Juarez de Oliveira, 2004.

AMARELLI, Francesco; DE GIOVANNI, Lucio; GARBARINO, Paolo; SCHIAVONE, Aldo; VINCENTI, Umberto. Storia del Diritto Romano. Torino: Giappichelli, 2000.

AMEAL, João. História de Portugal. 4. ed. Porto: Tavares Martins, 1958.

ANTONIAZZI, Alberto. A CNBB e a pastoral urbana; primeiros passos. In: MATOS, Henrique Cristiano José. Nossa História, 500 anos de presença da Igreja Católica no Brasil. São Paulo: Paulinas, 2011. t. 3.

ANUÁRIO Católico do Brasil. Rio de Janeiro: Ceris, 2012. v. 13.

ARRANGIO-RUIZ, Vincenzo. Istituzioni di Diritto Romano. Nápoles: Casa Editrice Dott. Eugenio Jovene, 1994.

BARDY, Gustave. La conversione al cristianesimo nei primi secoli. 8. ed. Milão: Jaca Books, 2015.

BERSANI, Carlo. Il pluralismo dei soggetti, modello dell'opera pia e disciplina della personalità dai codici preunitari all'Unità. Milão: Giuffrè, 1997.

BEVILAQUA, Clóvis. Código Civil dos Estados Unidos do Brasil comentado. Rio de Janeiro: Francisco Alves, 1916. v. I.

BEVILAQUA, Clóvis. Theoria geral do Direito Civil. 2. ed. Rio de Janeiro: Francisco Alves, 1929.

BIBLIA Sacra juxta Vulgatam Clementinam. Londres: Baronius Press, 2008.

Bíblia Sagrada. Trad. Padre Antonio Pereira de Figueiredo. Barsa, 1966.

BRAGA DA CRUZ, Guilherme. O direito subsidiário na história do Direito português. Revista Portuguesa de História, Coimbra, t. XIV, 1975.

BROWNLIE, Ian. Princípios de Direito Internacional Público. 4. ed. Lisboa: Fundação Calouste Gulbenkian, 1990. 
BUENO, José Antonio Pimenta; o Marquês de São Vicente. Direito Público brasileiro e análise da Constituição do Império. Rio de Janeiro: Ministério da Justiça e Negócios Interiores, Secretaria de Documentação, 1958.

CAETANO, Marcello. História do Direito português: 1140-1495. Lisboa: Verbo, 1981.

CAETANO, Marcello. Recepção e execução dos decretos do Concílio de Trento em Portugal. Lisboa, 1965.

CALMON, Pedro. História do Brasil. Rio de Janeiro: José Olympio, 1959. 7 v.

CÂMARA, José Gomes B. Subsidios para a história do Direito pátrio. Rio de Janeiro: Brasiliana, 1966. t. III.

CAMMEO, Federico. Ordinamento giuridico dello Stato della Città del Vaticano. Reedição da edição de 1932. Cidade do Vaticano: Libreria Editrice Vaticana, 2005.

CAMPOS, Antonio Macedo de. Comentários à Lei de Registros Públicos. Bauru: Jalovi, 1977.

CÂNDIDO, Austréia Magalhães. Da pessoa jurídica no Direito Romano. Revista da Faculdade de Direito da Universidade de São Paulo, v. 105, jan.-dez. 2010.

CARMIGNANI, Maria Cristina da Silva. O Direito judiciário lusitano - os assentos da Casa da Suplicação. Revista da Faculdade de Direito da Universidade de São Paulo, v. 111, 2016.

CARNEIRO, Júlio Maria de Morais. O catolicismo no Brasil. Belo Horizonte: Cristo Rei, 2017.

CATECISMO Romano. Traduzido para o português baseado na versão autêntica de 1566 por frei Leopoldo Pires Martins, O.F.M, 1951.

CENEVIVA, Walter. Lei dos Registros Públicos comentada. 6. ed. São Paulo: Saraiva, 1988.

CESARÉIA, Eusébio de. História eclesiástica. 2 ed. São Paulo: Paulus, 2008.

CHIAPPETTA, Luigi. Il Codice di Diritto Canonico, commento giuridico-pastorale. 3. ed. Bolonha: Edizione Dehoniane Bologna, 2011. 3 t.

Corpus iuris canonici: Editio Lipsiensis secunda post Aemilii Ludouici Richteri curas ad librorum manu scriptorum et editionis Romanae fidem recognouit et adnotatione critica instruit Aemilius Friedberg. Liepzig: Tauchnitz, 1879-1881.

CORTEZÃO, Jaime. A expedição de Cabral. A história da colonização portuguesa do Brasil. Porto: Litografia Nacional, 1923. v. II.

COSTA, Mário Júlio Almeida. História do Direito português. Coimbra: Almedina, 2002. 
DANIEL-ROPS. A Igreja dos apóstolos e dos mártires. São Paulo: Quadrante, 1988.

DAWSON, Christopher. A divisão da cristandade: da reforma protestante à era do iluminismo. São Paulo: É Realizações, 2014.

DE BIASIO, M. Gabriella Zoz. Premesse esegetiche allo studio del Diritto Romano. Torino: Giappichelli, 1995.

DENZINGER, Heinrich Joseph Dominicus. Enchiridion Symbolorum: definitionum et declarationum de rebus fidei et morum. org. Peter Hünermann. 43. ed. Bolonha: EDB, 2010.

DI DONATO, Stefano. Compendio di storia delle fonti del Diritto Canonico. Vaticano: Libreria Editrice Vaticana, 2014.

DIAS, Carlos Malheiros. História da colonização portuguesa do Brasil. Porto: Litografia Nacional, 1923.

DICIONÁRIO da língua portuguesa. Porto: Porto Editora, s.d.

DORNAS FILHO, João. O padroado e a Igreja brasileira. São Paulo: Nacional, 1938.

DUARTE, Nestor. Comentário ao artigo 44 do Código Civil. Código Civil comentado: doutrina e jurisprudência. Manole, São Paulo, 2007.

ERDÖ, Péter. Storia delle fonti del Diritto Canonico. Veneza: Marcianum Press, 2008. Ebook.

FANTINI, M. Grazia. La riflessione medievale sulla persona giuridica: la causa pia. Veneza: Marcianum Press, 2010.

FEITLER, Bruno; SOUZA, Evergton Sales. Estudo introdutório. Constituições primeiras do Arcebispado da Bahia. São Paulo: Edusp, 2010.

FERRANTE, Mario. La responsabilità penale delle persone giuridiche nel Diritto Canonico. Roma: Aracne, 2013.

FERREIRA, Pinto. Comentários à Constituição brasileira. Saraiva: São Paulo, 1989. v. 1.

FERREIRA, Waldemar Martins. História do Direito Constitucional brasileiro. São Paulo: Max Limonad, 1954.

FERREIRA, Waldemar. História do Direito brasileiro: as capitanias coloniais de juro e herdade. São Paulo: Saraiva, 1962. v. I.

FERREIRA, Waldemar. O casamento religioso de efeitos civis. São Paulo: Typographia Siqueira, 1935.

FONDAROLI, Désirée; ASTROLOGO, Annamaria; SILVESTRI, Giuseppe. Responsabilità "amministrativa" ex d. lgs. n. 231 del 2001 ed enti ecclesiastici civilmente riconosciuti. Stato, Chiese e pluralismo confessionale, n. 38, 2012. 
FREITAS, Augusto Teixeira de. Consolidação das leis civis. 3. ed. Rio de Janeiro: Garnier, 1876.

GALVÃO DE SOUSA, José Pedro. Introdução à história do Direito político brasileiro. São Paulo: Saraiva, 1962.

GILISSEN, John. Introdução histórica ao Direito. 2. ed. Lisboa: Fundação Calouste Gulbenkian, 1995.

GOMES DA SILVA, Nuno José. História do Direito português. 6. ed. Lisboa: Fundação Calouste Gulbenkian, 2016.

GOMES DA SILVA, Nuno José. Humanismo e Direito em Portugal no século XVI. 1964. Tese (Doutorado em Ciências Histórico-Jurídicas), Faculdade de Direito da Universidade de Lisboa, Lisboa, 1964.

GROSSO, Giuseppe. Lezioni di storia del Diritto Romano. 5. ed. Torino: Giappichelli, 1965.

LACERDA DE ALMEIDA, Francisco José. A Igreja e o Estado: suas relações no Direito brasileiro. Rio de Janeiro: Revista dos Tribunais, 1924.

LE TOURNEAU, Dominique. O Direito da Igreja. Lisboa: Diel, 1998.

LEITE, Serafim. História da Companhia de Jesus no Brasil. Lisboa: Portucalia, 1938. t. I.

LIMA, Maurílio Cesar de, Mons. Breve história da Igreja no Brasil. São Paulo: Loyola, 2004.

LIMA, Maurílio Cesar de, Mons. Introdução à história do Direito Canônico. São Paulo: Loyola, 2004.

LO CASTRO, Gaetano. Il mistero del Diritto, II. Persona e Diritto nella Chiesa. Turim: Giappichelli, 2011.

LO IACONO, Pietro. La natura funzionale della personalità giuridica nel Diritto Ecclesiastico. Nápoles: Jovene, 2000.

LOUREIRO, Luiz Guilherme. Registros públicos: teoria e prática. 8. ed. Salvador: Juspodivm, 2017.

MARTINS JÚNIOR, Isidoro. História do Direito nacional. Brasília: Imprensa Nacional, 1979.

MATOS, Henrique Cristiano José. Nossa História, 500 anos de presença da Igreja Católica no Brasil. São Paulo: Paulinas, 2011. t. 3.

MEDEIROS, José. Usos e cerimônias da nossa Ordem de Cristo. Sintra: Zéfiro, 2008. 
MENDES DE ALMEIDA, Cândido. Código Filipino ou Ordenações e Leis do Reino de Portugal recompiladas por mandado d'el Rei D. Filipe I. Edição fac-similar. Brasília: Senado Federal, 2012.

MONTEIRO, Washington de Barros. Curso de Direito Civil. 5. ed. São Paulo: Saraiva, 1966.

MONTEIRO, Washington de Barros. Curso de Direito Civil. São Paulo: Saraiva, 1960.

MUSSELLI, Luciano. Storia del Diritto Canonico: introduzione alla storia del Diritto e delle istituzioni ecclesiali. Torino: Giappichelli, 2007.

NABUCO, Joaquim. O partido ultramontano e suas invasões, seus órgãos e seu futuro. Rio de Janeiro: Tipografia da Reforma, 1873. Apud: VIEIRA, Dilermando Ramos. História do catolicismo no Brasil. Aparecida: Santuário, 2016. v. 1.

NDI, Joseph Clifford N. Contracts between ecclesiastical entities according to canon law. Berlim: Logos, 2018.

NICOLÒ, Angela Maria Punzi. La persona giuridica in Diritto Canonico. Persone giuridiche e storia del Diritto. Torino: Giappichelli, 2004.

NORONHA, Ibsen. Incursões jurídico-históricas sobre as relações entre a Igreja Católica e o Brasil - do Descobrimento à Independência. In: BALDISSERI, Lorenzo; MARTINS FILHO, Ives Gandra da Silva (coord.). Acordo Brasil-Santa Sé comentado. São Paulo: LTr, 2012.

ONOFRI, Renato Sedano. A construção de uma tradição jurídica: memória, esquecimento e codificação civil brasileira. 2017. Tese (Doutorado em Direito), Faculdade de Direito da Universidade de São Paulo, São Paulo, 2017.

ORESTANO, Riccardo. "Persona" e "persone giuridiche" nell'Età Moderna. Persone giuridiche e storia del Diritto. Torino: Giappichelli, 2004.

PASNAU, Robert; VAN DYKE, Christina (coord.). The Cambridge History of Medieval Philosophy. 2. ed. Cambridge: Cambridge University Press, 2014. 2 t.

PEREIRA, Caio Mário da Silva. Instituições de Direito Civil. Rio de Janeiro: Forense, 1961. V. 1.

PERES, Damião. História de Portugal. Barcelos: Portucalense, 1931.

PONTES DE MIRANDA, Francisco Cavalcanti. Tratado de Direito Privado: parte geral. Rio de Janeiro: Borsoi, 1954. t. I.

POVEDA VELASCO, Ignacio Maria. Ordenações do Reino de Portugal. Revista da Faculdade de Direito da Universidade de São Paulo, v. 89, 1994.

POVEDA VELASCO, Ignacio Maria. Os esponsais no Direito luso-brasileiro. São Paulo: Quartier Latin, 2007. 
RAMOS, André de Carvalho; e GRAMSTRUP, Erik Frederico. Comentários à Lei de Introdução às Normas do Direito Brasileiro. São Paulo: Saraiva, 2016.

RHODE, Ulrich. La personalità giuridica degli enti ecclesiastici negli ordinamenti civili. Periodica, v. 105, 2016. In: NDI, Joseph Clifford N. Contracts between ecclesiastical entities according to canon law. Berlim: Logos, 2018.

RIBAS, Antonio Joaquim. Curso de Direito Civil brasileiro. Rio de Janeiro: Garnier, 1880. t. II.

ROBL FILHO, Ilton Norberto. Conselho Nacional de Justiça: Estado democrático de Direito e accountability. São Paulo: Saraiva, 2013.

RODRIGUES, Antônio Coelho. Projeto do Código Civil brasileiro. 2. ed. Brasília: Ministério da Justiça, 1980.

RODRIGUES, Silvio. Direito Civil. 26. ed. São Paulo: Saraiva, 1996.

RODRIGUES, Silvio. Direito Civil: parte geral. 19. ed. São Paulo: Saraiva, 1988.

SALVADOR, C. Corral; EMBIL, J. M. Urteaga. Dicionário de Direito Canônico. São Paulo: Loyola, 1997.

SCELLINI, Giuseppe. Storia del Diritto Canonico. Milão: Giuffrè, 2014.

SERRA, Beatrice. Sull'estinzione e modificazione della persona giuridica nel Diritto Canonico moderno. Supunti ricostruttivi per una teoria dei soggetti di diritto. Ius Ecclesiae, n. XXII, 2010.

SILVA, Maria Beatriz Nizza da (coord.). Dicionário da história da colonização portuguesa no Brasil. Lisboa: Verbo, 1994.

SILVA, Regina Beatriz Tavares da (coord.). Código Civil comentado. 9. ed. São Paulo: Saraiva, 2013.

SPRIZZI, Marco. Art. $3^{\circ}$ Personalidade jurídica. In: BALDISSERI, Lorenzo; MARTINS FILHO, Ives Gandra da Silva (coord.). Acordo Brasil-Santa Sé comentado. São Paulo: LTr, 2012.

TEIXEIRA DE FREITAS, Augusto. Código Civil: esboço. Brasília: Imprensa Nacional, 1983.

TRIPOLI, César. História do Direito brasileiro. São Paulo: Revista dos Tribunais, São Paulo, 1936. [1947. v. II. t. I]

TUCCI, José Rogério Cruz e; AZEVEDO, Luiz Carlos de. Lições de Processo Civil Canônico. São Paulo: Revista dos Tribunais, 2001. 
VALDRINI, Patrick. Le persone giuridiche. In: D'ARIENZO, Maria; MUSSELLI, Luciano; TEDESCHI, Mario; VALDRINI, Patrick. Manuale di Diritto Canonico. Torino: Giappichelli, 2016.

VAN DE WIEL, Constant. History of Canon Law. Louvain: Peeters, s.d. E-book.

VIANNA, Hélio. História do Brasil. São Paulo: Melhoramentos, 1965. v. I e II.

VIEHWEG. Tópica e jurisprudência, uma contribuição à investigação dos fundamentos jurídicos-científicos. Porto Alegre: Fabris, 2008.

VIEIRA, Dilermando Ramos. História do catolicismo no Brasil. Aparecida: Santuário, 2016. v. 1. 


\section{APÊNDICE A - Proposta de Projeto de Lei}

\section{Projeto de Lei n. XXX}

Altera a Lei Federal n. 6.015, de 31 de dezembro de 1973, para fazer constar disposições específicas que dão cumprimento ao Decreto $n$. 7.107, de 11 de fevereiro de 2010, o qual dá execução ao Acordo relativo ao Estatuto Jurídico da Igreja Católica no Brasil, celebrado em 13 de novembro de 2008 entre o Governo da República Federativa do Brasil e a Santa Sé.

Art. XX. As Instituições Eclesiásticas nomeadas no art. $3^{\circ}$ do Acordo Brasil-Santa Sé que possuem personalidade jurídica em conformidade com o Direito Canônico adquirirão personalidade jurídica no ordenamento brasileiro mediante o registro realizado em Registro Civil de Pessoas Jurídicas.

Art. XX. Os documentos necessários para o registro serão os seguintes:

$\S 1^{\circ}$ No caso de Dioceses:

I - Bula Papal de criação da Diocese;

II - Bula de nomeação do Bispo Diocesano; e

III - Ata de posse do Bispo Diocesano.

$\S 2^{\circ}$ Nos demais casos:

I - Documento da autoridade canônica competente com o ato de criação da pessoa jurídica;

II - Documento de nomeação da autoridade competente que assinou o ato de criação da pessoa jurídica; e

III - Estatutos da pessoa jurídica criada, quando for o caso.

$\S 3^{\circ}$ Os documentos apresentados em língua estrangeira deverão estar acompanhados da correspondente tradução juramentada.

Art. XX. Apresentados os documentos indicados no $\S 1^{\circ}$ do art. XX e estando eles em boa ordem, procederá o oficial do registro com a inscrição e registro da Instituição Eclesiástica.

Parágrafo único. Eventuais alterações nos estatutos das Instituições Eclesiásticas serão registradas no mesmo Registro Civil de Pessoas Jurídicas, bastando, para tanto, a 
apresentação do instrumento de modificação, acompanhado de sua respectiva tradução juramentada para o português, quando aplicável.

Art. XX. Os Registros Civis de Pessoas Jurídicas manterão livro específico para a escrituração e registro de Instituições Eclesiásticas. 


\title{
ANEXO A - Acordo Brasil-Santa Sé
}

\section{ACORDO ENTRE A REPÚBLICA FEDERATIVA DO BRASIL E A SANTA SÉ RELATIVO AO ESTATUTO JURÍDICO DA IGREJA CATÓLICA NO BRASIL}

\author{
A República Federativa do Brasil \\ e \\ A Santa Sé \\ (doravante denominadas Altas Partes Contratantes),
}

Considerando que a Santa Sé é a suprema autoridade da Igreja Católica, regida pelo Direito Canônico;

Considerando as relações históricas entre a Igreja Católica e o Brasil e suas respectivas responsabilidades a serviço da sociedade e do bem integral da pessoa humana;

Afirmando que as Altas Partes Contratantes são, cada uma na própria ordem, autônomas, independentes e soberanas e cooperam para a construção de uma sociedade mais justa, pacífica e fraterna;

Baseando-se, a Santa Sé, nos documentos do Concílio Vaticano II e no Código de Direito Canônico, e a República Federativa do Brasil, no seu ordenamento jurídico;

Reafirmando a adesão ao princípio, internacionalmente reconhecido, de liberdade religiosa;

Reconhecendo que a Constituição brasileira garante o livre exercício dos cultos religiosos;

Animados da intenção de fortalecer e incentivar as mútuas relações já existentes;

Convieram no seguinte:

\section{Artigo $1^{\circ}$}

As Altas Partes Contratantes continuarão a ser representadas, em suas relações diplomáticas, por um Núncio Apostólico acreditado junto à República Federativa do Brasil e por um Embaixador(a) do Brasil acreditado(a) junto à Santa Sé, com as imunidades e garantias asseguradas pela Convenção de Viena sobre Relações Diplomáticas, de 18 de abril de 1961, e demais regras internacionais. 


\section{Artigo $2^{\circ}$}

A República Federativa do Brasil, com fundamento no direito de liberdade religiosa, reconhece à Igreja Católica o direito de desempenhar a sua missão apostólica, garantindo o exercício público de suas atividades, observado o ordenamento jurídico brasileiro.

\section{Artigo $3^{\circ}$}

A República Federativa do Brasil reafirma a personalidade jurídica da Igreja Católica e de todas as Instituições Eclesiásticas que possuem tal personalidade em conformidade com o direito canônico, desde que não contrarie o sistema constitucional e as leis brasileiras, tais como Conferência Episcopal, Províncias Eclesiásticas, Arquidioceses, Dioceses, Prelazias Territoriais ou Pessoais, Vicariatos e Prefeituras Apostólicas, Administrações Apostólicas, Administrações Apostólicas Pessoais, Missões Sui Iuris, Ordinariado Militar e Ordinariados para os Fiéis de Outros Ritos, Paróquias, Institutos de Vida Consagrada e Sociedades de Vida Apostólica.

$\S 1^{\mathrm{o}}$ A Igreja Católica pode livremente criar, modificar ou extinguir todas as Instituições Eclesiásticas mencionadas no caput deste artigo.

$\S 2^{\circ}$ A personalidade jurídica das Instituições Eclesiásticas será reconhecida pela República Federativa do Brasil mediante a inscrição no respectivo registro do ato de criação, nos termos da legislação brasileira, vedado ao poder público negar-lhes reconhecimento ou registro do ato de criação, devendo também ser averbadas todas as alterações por que passar $\mathrm{o}$ ato.

\section{Artigo $4^{\circ}$}

A Santa Sé declara que nenhuma circunscrição eclesiástica do Brasil dependerá de Bispo cuja sede esteja fixada em território estrangeiro.

Artigo $5^{\circ}$

As pessoas jurídicas eclesiásticas, reconhecidas nos termos do Artigo $3^{\circ}$, que, além de fins religiosos, persigam fins de assistência e solidariedade social, desenvolverão a própria atividade e gozarão de todos os direitos, imunidades, isenções e benefícios atribuídos às entidades com fins de natureza semelhante previstos no ordenamento jurídico brasileiro, desde que observados os requisitos e obrigações exigidos pela legislação brasileira.

\section{Artigo $6^{\circ}$}

As Altas Partes reconhecem que o patrimônio histórico, artístico e cultural da Igreja Católica, assim como os documentos custodiados nos seus arquivos e bibliotecas, constituem parte relevante do patrimônio cultural brasileiro, e continuarão a cooperar para salvaguardar, valorizar e promover a fruição dos bens, móveis e imóveis, de propriedade da Igreja Católica 
ou de outras pessoas jurídicas eclesiásticas, que sejam considerados pelo Brasil como parte de seu patrimônio cultural e artístico.

$\S 1^{\circ}$ A República Federativa do Brasil, em atenção ao princípio da cooperação, reconhece que a finalidade própria dos bens eclesiásticos mencionados no caput deste artigo deve ser salvaguardada pelo ordenamento jurídico brasileiro, sem prejuízo de outras finalidades que possam surgir da sua natureza cultural.

$\S 2^{\circ}$ A Igreja Católica, ciente do valor do seu patrimônio cultural, compromete-se a facilitar o acesso a ele para todos os que o queiram conhecer e estudar, salvaguardadas as suas finalidades religiosas e as exigências de sua proteção e da tutela dos arquivos.

Artigo $7^{\circ}$

A República Federativa do Brasil assegura, nos termos do seu ordenamento jurídico, as medidas necessárias para garantir a proteção dos lugares de culto da Igreja Católica e de suas liturgias, símbolos, imagens e objetos cultuais, contra toda forma de violação, desrespeito e uso ilegítimo.

$\S 1^{\circ}$ Nenhum edifício, dependência ou objeto afeto ao culto católico, observada a função social da propriedade e a legislação, pode ser demolido, ocupado, transportado, sujeito a obras ou destinado pelo Estado e entidades públicas a outro fim, salvo por necessidade ou utilidade pública, ou por interesse social, nos termos da Constituição brasileira.

\section{Artigo $8^{\circ}$}

A Igreja Católica, em vista do bem comum da sociedade brasileira, especialmente dos cidadãos mais necessitados, compromete-se, observadas as exigências da lei, a dar assistência espiritual aos fiéis internados em estabelecimentos de saúde, de assistência social, de educação ou similar, ou detidos em estabelecimento prisional ou similar, observadas as normas de cada estabelecimento, e que, por essa razão, estejam impedidos de exercer em condições normais a prática religiosa e a requeiram. A República Federativa do Brasil garante à Igreja Católica o direito de exercer este serviço, inerente à sua própria missão.

Artigo $9^{\circ}$

O reconhecimento recíproco de títulos e qualificações em nível de graduação e pósgraduação estará sujeito, respectivamente, às exigências dos ordenamentos jurídicos brasileiro e da Santa Sé. 
A Igreja Católica, em atenção ao princípio de cooperação com o Estado, continuará a colocar suas instituições de ensino, em todos os níveis, a serviço da sociedade, em conformidade com seus fins e com as exigências do ordenamento jurídico brasileiro.

$\S 1^{\circ}$ A República Federativa do Brasil reconhece à Igreja Católica o direito de constituir e administrar Seminários e outros Institutos eclesiásticos de formação e cultura.

$\S 2^{\circ} \mathrm{O}$ reconhecimento dos efeitos civis dos estudos, graus e títulos obtidos nos Seminários e Institutos antes mencionados é regulado pelo ordenamento jurídico brasileiro, em condição de paridade com estudos de idêntica natureza.

\section{Artigo 11}

A República Federativa do Brasil, em observância ao direito de liberdade religiosa, da diversidade cultural e da pluralidade confessional do País, respeita a importância do ensino religioso em vista da formação integral da pessoa.

$\S 1^{\circ} \mathrm{O}$ ensino religioso, católico e de outras confissões religiosas, de matrícula facultativa, constitui disciplina dos horários normais das escolas públicas de ensino fundamental, assegurado o respeito à diversidade cultural religiosa do Brasil, em conformidade com a Constituição e as outras leis vigentes, sem qualquer forma de discriminação.

\section{Artigo 12}

O casamento celebrado em conformidade com as leis canônicas, que atender também às exigências estabelecidas pelo direito brasileiro para contrair o casamento, produz os efeitos civis, desde que registrado no registro próprio, produzindo efeitos a partir da data de sua celebração.

$\S 1^{\mathrm{o}} \mathrm{A}$ homologação das sentenças eclesiásticas em matéria matrimonial, confirmadas pelo órgão de controle superior da Santa Sé, será efetuada nos termos da legislação brasileira sobre homologação de sentenças estrangeiras.

\section{Artigo 13}

É garantido o segredo do ofício sacerdotal, especialmente o da confissão sacramental. Artigo 14

A República Federativa do Brasil declara o seu empenho na destinação de espaços a fins religiosos, que deverão ser previstos nos instrumentos de planejamento urbano a serem estabelecidos no respectivo Plano Diretor. 
Às pessoas jurídicas eclesiásticas, assim como ao patrimônio, renda e serviços relacionados com as suas finalidades essenciais, é reconhecida a garantia de imunidade tributária referente aos impostos, em conformidade com a Constituição brasileira.

$\S 1^{\circ}$ Para fins tributários, as pessoas jurídicas da Igreja Católica que exerçam atividade social e educacional sem finalidade lucrativa receberão o mesmo tratamento e benefícios outorgados às entidades filantrópicas reconhecidas pelo ordenamento jurídico brasileiro, inclusive, em termos de requisitos e obrigações exigidos para fins de imunidade e isenção.

\section{Artigo 16}

Dado o caráter peculiar religioso e beneficente da Igreja Católica e de suas instituições:

I - O vínculo entre os ministros ordenados ou fiéis consagrados mediante votos e as Dioceses ou Institutos Religiosos e equiparados é de caráter religioso e portanto, observado o disposto na legislação trabalhista brasileira, não gera, por si mesmo, vínculo empregatício, a não ser que seja provado o desvirtuamento da instituição eclesiástica.

II - As tarefas de índole apostólica, pastoral, litúrgica, catequética, assistencial, de promoção humana e semelhantes poderão ser realizadas a título voluntário, observado o disposto na legislação trabalhista brasileira.

\section{Artigo 17}

Os Bispos, no exercício de seu ministério pastoral, poderão convidar sacerdotes, membros de institutos religiosos e leigos, que não tenham nacionalidade brasileira, para servir no território de suas dioceses, e pedir às autoridades brasileiras, em nome deles, a concessão do visto para exercer atividade pastoral no Brasil.

$\S 1^{\circ} \mathrm{Em}$ consequência do pedido formal do Bispo, de acordo com o ordenamento jurídico brasileiro, poderá ser concedido o visto permanente ou temporário, conforme o caso, pelos motivos acima expostos.

\section{Artigo 18}

O presente acordo poderá ser complementado por ajustes concluídos entre as Altas Partes Contratantes.

$\S 1^{\circ}$ Órgãos do Governo brasileiro, no âmbito de suas respectivas competências e a Conferência Nacional dos Bispos do Brasil, devidamente autorizada pela Santa Sé, poderão celebrar convênio sobre matérias específicas, para implementação do presente Acordo. 
Quaisquer divergências na aplicação ou interpretação do presente acordo serão resolvidas por negociações diplomáticas diretas.

\title{
Artigo 20
}

O presente acordo entrará em vigor na data da troca dos instrumentos de ratificação, ressalvadas as situações jurídicas existentes e constituídas ao abrigo do Decreto n. 119-A, de 7 de janeiro de 1890, e do Acordo entre a República Federativa do Brasil e a Santa Sé sobre Assistência Religiosa às Forças Armadas, de 23 de outubro de 1989.

Feito na Cidade do Vaticano, aos 13 dias do mês de novembro do ano de 2008, em dois originais, nos idiomas português e italiano, sendo ambos os textos igualmente autênticos.

\author{
PELA REPÚBLICA FEDERATIVA DO BRASIL \\ Celso Amorim \\ Ministro das Relações Exteriores \\ PELA SANTA SÉ \\ Dominique Mamberti \\ Secretário para Relações com os Estados
}

